\title{
PENGEMBANGAN BAHAN AJAR BERBASIS WORKSHEET MATA KULIAH BIOLOGI LAUT UNTUK MENINGKATKAN SIKAP ILMIAH MAHASISWA
}

\author{
Haerunnisa \\ Pengajar STKIP Puangrimaggalatung Sengkang \\ email : nisa.prima77@yahoo.co.id \\ Ahmad Yani \\ Pengajar STKIP Puangrimaggalatung Sengkang, \\ email : ahyan@yahoo.co.id \\ Cici Andani \\ Mahasiswa Pasca Sarjana UNM \\ Jurusan Pendidikan Biologi \\ Email : andanicici7@gmail.com
}

\begin{abstract}
Abstrak
Penelitian ini bertujuan untuk mengembangkan lembar kerja mata kuliah Biologi Laut dan untuk mengetahui peningkatan sikap ilmiah mahasiswa STKIP Puangrimaggalatung Sengkang melalui pengembangan lembar kerja mata kuliah Biologi Laut. Subyek dalam penelitian ini adalah lembar kerja mata kuliah Biologi Laut sedangkan responden penelitian adalah 30 mahasiswa dan 2 dosen mata kuliah Biologi Laut (observer dan validator). Dalam penelitian ini dilakukan penilaian sikap ilmiah dan tiga kali tes untuk hasil belajar mahasiswa yaitu pretest sebelum pembelajaran, posttest I setelah pembelajaran tanpa lembar kerja dan posttest II setelah pembelajaran dengan lembar kerja. Instrumen yang digunakan dalam penelitian berupa angket validasi materi dan desain, angket persepsi mahasiswa, lembar observasi penilaian sikap ilmiah dan tes uraian tertulis.Data yang terkumpul dianalisis secara kuantitatif dan kualitatif. Data validasi materi dan desain diperoleh dari penilaian dosen mata kuliah Biologi Laut, data persepsi mahasiswa diperoleh dari tanggapan mahasiswa, data sikap ilmiah diperoleh dari hasil pengamatan observer I dan observer II saat pembelajaran berlangsung dan data hasil belajar diperoleh dari tes uraian tertulis mahasiswa. Hasil penelitian menunjukkan bahwa: (1) Lembar kerja Biologi Laut yang dikembangkan layak untuk digunakan berdasarkan penilaian ahli materi sebanyak 87,87\% dengan kategori sangat layak, ahli media sebanyak $82,14 \%$ dengan kategori sangat layak dan tanggapan setuju mahasiswa sebanyak 90\%. (2) Pengembangan lembar kerja mata kuliah Biologi Laut mampu meningkatkan sikap ilmiah mahasiswa STKIP Puangrimaggalatung Sengkang. Hal ini terbukti dari rata-rata persentase hasil penelitian sikap ilmiah sebelum penggunaan lembar kerja sebanyak $56 \%$ dan setelah penggunaan lembar kerja sebanyak 83,04\%.
\end{abstract}

Kata Kunci: Pengembangan bahan ajar, Lembar Kerja (Worksheet), Biologi Laut, Sikap Ilmiah. 


\begin{abstract}
This study aims to develop worksheets of Marine Biology courses and to find out the improvement of scientific attitudes of STKIP Puangrimaggalatung Sengkang students through the development of a worksheet on Marine Biology. The subjects in this study were worksheets of Marine Biology courses while the research respondents were 30 students and 2 lecturers of Marine Biology (observers and validators). In this study a scientific attitude assessment and three tests were conducted for student learning outcomes namely pretest before learning, posttest I after learning without worksheets and posttest II after learning with worksheets. The instruments used in the study were material and design validation questionnaires, student perception questionnaires, scientific attitude assessment observation sheets and written description tests. The collected data were analyzed quantitatively and qualitatively. Material and design validation data were obtained from the assessment of lecturers of Marine Biology courses, student perceptions data were obtained from student responses, scientific attitudes data were obtained from observers I and observer II observations when learning took place and learning outcome data were obtained from students' written description tests. The results showed that: (1) the Marine Biology worksheet developed was feasible to use based on the assessment of material experts as much as $87.87 \%$ with very feasible categories, media experts as much as $82.14 \%$ with very feasible categories and agreeing responses of students as much as 90\%. (2) Development of worksheets on Marine Biology courses can improve the scientific attitude of STKIP Puangrimaggalatung Sengkang students. This is evident from the average percentage of research results of scientific attitudes before the use of worksheets as much as $56 \%$ and after the use of worksheets as much as $83.04 \%$.
\end{abstract}

Keywords: Development of teaching materials, Worksheets, Marine Biology, Scientific Attitudes.

\title{
PENDAHULUAN
}

Biologi merupakan suatu ilmu pengetahuan yang tidak terlepas dari fakta, konsep, dalil dan prinsip yang berkaitan dengan makhluk hidup, serta interaksinya dengan lingkungan.Biologi memerlukan pemahaman, aplikasi, analisis, sintesis dan evaluasi atau berfikir tingkat tinggi. Dalam belajar biologi harus menggunakan pertanyaan apa, kenapa dan bagaimana (Lufri, dkk, 2007; Megahati S, dkk, 2015.

Biologi sebagai salah satu produk sains memiliki peranan penting dalam meningkatkan mutu pendidikan khususnya menghasilkan mahasiswa yang berkualitas dan berinisiatif serta mampu menemukan konsep dalam suatu proses pembelajaran, mengkaitkan konsep-konsep tersebut menjadi suatu pembelajaran dalam rangka menghadapi persaingan di era globalisasi yang diakibatkan oleh dampak perkembangan sains (Nuryani, 2005; Eka Trisianawati dan Handy Darmawan, 2017). 
Biologi sebagai salah satu bidang Ilmu Pengetahuan Alam yang menyediakan berbagai pengalaman belajar untuk memahami konsep dan proses sains. Biologi dikembangkan melalui kemampuan berpikir analisis, induktif, dan deduktif untuk menyelesaikan masalah yang berkaitan dengan peristiwa alam sekitar (Suryana, dkk, 2013)

Sikap ilmiah adalah bagian dari proses sains. Sikap ilmiah Merupakan kesesuaian tingkah laku mahasiswa terhadap proses belajar mengajar. Adapun ciri-ciri pelajar memiliki sikap ilmiah antara lain memiliki rasa ingin tahu, tidak menerima kebenaran tanpa bukti, jujur, teliti, menghargai pendapat orang lain, sanggup menerima gagasan baru dan semangat baru. Sikap ilmiah ini sangat diperlukan dalam mempelajari sains khususnya bidang biologi (Hidayati, 2014; Suryani, 2013). Wahyudi (2011) menyatakan sikap ilmiah dapat mempengaruhi prestasi belajar baik pada aspek kognitif, afektif, maupun psikomotorik. Jika mahasiswa memiliki sikap ilmiah maka memiliki motivasi yang tinggi untuk terus mengembangkan potensi diri dan meningkatkan pemahaman konsep yang pada akhirnya akan meningkatkan hasil belajar mahasiswa (Ahmad Yani, dkk, 2017).

Program Studi Pendidikan Biologi STKIP Puangrimaggalatung Sengkang menggunakan Kualifikasi Kurikulum Nasional Indonesia (KKNI) 2016 dalam perkuliahannya, dimana terdapat mata kuliah keilmuan dan keterampilan (MKK).Mata kuliah Biologi Laut tergabung dalam kelompok MKK tersebut dengan bobot 2 SKS yang sesuai dengan KKNI 2016. Mata kuliah ini membahas keanekaragaman biota air laut (tumbuhan, hewan, dan mikroorganisme laut), eksplorasi, pemanfaatan dan konservasi organisme laut serta interaksi antar biota air laut dan lingkungannya. Penyajian mata kuliah Biologi Laut terintegrasi antara teori dan praktik dalam hal ini kemampuan dan hasil belajar mahasiswa ditentukan secara utuh meliputi 3 aspek penting yaitu ranah kognitif (pengetahuan), afektif (sikap), dan psikomotor (keterampilan).

Di dalam perkuliahan Biologi laut terdapat 3 tahapan perkuliahan yang terdiri dari penyampaian materi oleh dosen, diskusi kelompok dan pelaksanaan praktikum.Ketiga tahapan tersebut merupakan cerminan kerja ilmiah yang merupakan kegiatan dalam perkuliahan Biologi Laut. Biologi Laut merupakan mata kuliah yang 
tidak hanya menguasai materi, namun materi tersebut nantinya akan dipraktikumkan langsung di lapangan, sehingga sangat diperlukan sikap ilmiah yang bagus.

Namun pada kenyataannya, menurut pengamatan peneliti, sikap ilmiah mahasiswa belum seperti yang diharapkan. Berdasarkan pengalaman sendiri dan informasi yang diperoleh dari mahasiswa pada mata kuliah Biologi Laut diketahui bahwa tuntutan sikap ilmiah dalam perkuliahan Biologi Laut masih jauh dari yang diharapkan. Hal ini disebabkan pembelajaran yang dilakukan cenderung lebih banyak berpusat pada dosen yang menciptakan kurangnya interaksi antara dosen dengan mahasiswa maupun mahasiswa dengan mahasiswa. Selain itu juga disebabkan oleh rendahnya tingkat kemandirian, percaya diri, rasa ingin tahu, ketelitian, tanggung jawab, kerja sama, ketelitian dan keterlibatan mahasiswa dalam proses kegiatan pembelajaran yang mengakibatkan mahasiswa cenderung pasif dan merasa tidak tertantang untuk mengikuti dan menguasai mata kuliah Biologi Laut. Diketahui juga bahwa pada saat mahasiswa ditugaskan untuk melakukan diskusi kelompok dalam pemecahan masalah, hanya sebagian dari mahasiswa yang mampu menyelesaikan masalah yang diberikan oleh dosen, sementara mahasiswa yang lain tidak fokus terhadap tugas yang diberikan dan lebih memilih bercerita dengan teman-temannya diluar materi perkuliahan. Hal ini membuktikan sikap kerja sama dan tanggung jawab mahasiswa dalam kelompok masih kurang.

Berdasarkan distribusi nilai akhir Biologi Laut semester genap 2016/2017 hanya $50 \%$ yang mendapatkan nilai tinggi dan 50\% juga mendapatkan nilai sedang (65-75). Hal ini menunjukkan bahwa mahasiswa belum mampu menerapkan sikap ilmiah dengan baik dalam pembelajaran Biologi Laut. Kurangnya implementasi sikap ilmiah mahasiswa dalam pembelajaran dapat berdampak buruk terhadap hasil belajar yang diperoleh.

Salah satu solusi yang dapat dilakukan untuk mengatasi masalah tersebut yaitu dengan mengembangkan worksheet berbasis keterampilan proses. Worksheet berbasis keterampilan proses sains yaitu worksheet yang mengembangkan keterampilan proses agar mahasiswa mampu menemukan dan mengembangkan fakta, konsep, sikap dan nilai yang dituntut.

Berdasarkan masalah di atas, maka tujuan dalam penelitian ini adalah untuk mengembangkan lembar kerja (worksheet) mata kuliah Biologi Laut dan mengetahui 
peningkatan sikap ilmiah mahasiswa STKIP Puangrimaggalatung Sengkang melalui pengembangan lembar kerja (worksheet) mata kuliah Biologi Laut.

\section{METODOLOGI PENELITIAN}

Penelitian ini dirancang sebagai penelitian Research and Development (R\&D) yang merupakan desain penelitian dan pengembangan yaitu metode penelitian yang digunakan untuk menghasilkan produk tertentu (Sugiyono, 2012) dalam Fitrianingsih Rahmatika, 2014. Dalam hal ini yang dikembangkan adalah Lembar Kerja (worksheet) pada mata kuliah Biologi Laut untuk meningkatkan sikap ilmiah mahasiswa STKIP Puangrimaggalatung Sengkang.

Prosedur dalam pengembangan lembar kerja ini mengadaptasi pada pengembangan perangkat model 4-D (four Dmodel).Menurut Endang Mulyatingsih (2012) dalam Rokhimawan, 2016. Pengembangan perangkat model 4-D (four Dmodel)yang terdiri dari 4 tahap pengembangan, yaitu Define, Design, Development, andDissemination. Dalam penelitian ini hanya dilakukan pada 3 tahap yaitu :Define, Design and Development.

Instrument pengumpulan data dalam penelitian pengembangan ini berupa: 1). Angket Validasi untuk Materi dan Media, digunakan untuk mengetahui apakah lembar kerja mata kuliah Biologi Laut untuk meningkatkan sikap ilmiah mahasiswa STKIP Puangrimaggalatung Sengkang telah dirancang layak atau tidak. 2). Angket Persepsi Mahasiswa terhadap Lembar Kerja. Angket persepsi mahasiswa digunakan untuk mengetahui bagaimana tanggapan atau umpan balik mahasiswa terhadap lembar kerja mata kuliah Biologi Laut. 3) Lembar Observasi Penilaian Sikap Ilmiah Mahasiswa. Lembar Observasi penilaian sikap ilmiah digunakan untuk mengetahui bagaimana peningkatan sikap ilmiah mahasiswa STKIP Puangrimaggalatung Sengkang dengan dikembangkannya sebuah lembar kerja mata kuliah Biologi Laut. 4) Tes uraian tertulis. Tes uraian tertulis sebagai evaluasi hasil belajar digunakan untuk mengetahui bagaimana peningkatan hasil belajar mahasiswa STKIP Puangrimaggalatung Sengkang dengan dikembangkannya sebuah lembar kerja mata kuliah Biologi Laut.

Teknik analisis data dalam penelitian ini berupa teknik analisis data kualitatif dan teknik analisis data kuantitatif.Data tentang instrumen penilaian validasi materi, media dan tanggapan/persepsi mahasiswa dianalisis dengan uji deskriptif persentase dengan rumus sebagai berikut (Sudijono, 2006:Rahmatika, 2014). 
$P=f / N \times 100 \%$

Keterangan :

$\mathrm{P}$ : skor yang diharapkan

$\mathrm{f}$ : jumlah skor yang diperoleh

$\mathrm{N}$ : jumlah skor maksimum

Kriteria yang diterapkan untuk penilaian validitas materi dan media dikonversikan menggunakan tabel 1 .

Tabel 1. Kriteria penilaian validitas materi, media dan tanggapan mahasiswa

\begin{tabular}{ll}
\hline Interval & Kriteria \\
\hline $25 \%<$ skor $\leq 43,75 \%$ & Tidak layak \\
$43,75 \%<$ skor $\leq 62,50 \%$ & Cukup layak \\
$62,50 \%<$ skor $\leq 81,25 \%$ & Layak \\
$81,25 \%<$ skor $\leq 100 \%$ & Sangat layak \\
\hline
\end{tabular}

Data tentang instrumen penilaian sikap ilmiah mahasiswa dianalisis dengan uji deskriptif persentase dengan rumus sebagai berikut (Sudijono, 2006: Rahmatika, 2014).

$P=f / N \times 100 \%$

Keterangan :

P : skor yang diharapkan

f : jumlah skor yang diperoleh

$\mathrm{N}$ : jumlah skor maksimum

Kriteria yang diterapkan untuk penilaian validitas media dan materi dikonversikan menggunakan tabel 2.

Tabel 2. Kriteria penilaian sikap ilmiah dan hasil belajar mahasiwa

\section{Interval}

$25 \%<$ skor $\leq 43,75 \%$

$43,75 \%<$ skor $\leq 62,50 \%$

$62,50 \%<$ skor $\leq 81,25 \%$

$81,25 \%<$ skor $\leq 100 \%$

\section{Kriteria}

Tidak Baik

Cukup Baik

Baik

Sangat Baik

Rata-rata validasi ahli materi dan media masing-masing mencapai $\geq 62,50 \%$ sesuai dengan instrumen penilaian lembar kerja mata kuliah Biologi Laut. Rata-rata 
persentase tanggapan mahasiswa terhadapa lembar kerja (worksheet) Biologi Laut mencapai minimal kriteria baik dengan skor $\geq 62,50 \%$. Rata-rata persentase sikap ilmiah dan hasil belajar mahasiswa mencapai minimal kriteria baik dengan skor $\geq 62,50$ $\%$.

\section{HASIL DAN PEMBAHASAN}

\section{Tahap define (pendefinisian)}

Prototipe lembar kerja pada mata kuliah Biologi Laut dirancang berdasarkan analisis awal. Kegiatan ini dimulai dari menganalisis masalah pada perkuliahan Biologi Laut, menganalisis silabus mata kuliah Biologi Laut, menganalisis buku teks Biologi Laut dan mereviuw literatur tentang lembar kerja. Pada tahapan ini, dilakukan analisis dari mata kuliah Biologi Laut yang merupakan analisis awal sebelum dilakukan pengembangan lembar kerja. Berdasarkan hasil observasi pada mata kuliah Biologi Laut diketahui bahwa mahasiswa selama perkuliahan hanya mengharapkan materi dari dosen saja. Mahasiswa juga hanya mengharapkan contoh soal dan tugas yang diberikan dosen. Tidak ada keinginan mahasiwa untuk menggali informasi lain dari buku teks yang ada. Mahasiswa hanya mengerjakan latihan jika latihan itu dikumpul.

Mahasiswa tidak mengerjakan soal-soal selain soal-soal yang diminta oleh dosen. Kadang-kadang mereka hanya menyalin pekerjaan temannya yang tergolong pintar. Bahkan sebagian dari mereka hanya menunggu pembahasan dosen ketika kuliah responsi. Hal ini disebabkan oleh rendahnya sikap ilmiah yang dimiliki mahasiswa seperti sikap keingintahuan, kerja sama, ketelitian, tanggung jawab dan berfikir kritis sehingga hasil belajar yang diperoleh oleh mahasiswa juga tidak sesuai dengan harapan. Untuk itu, pengembangan lembar kerja dirancang sedemikian rupa sehingga mahasiswa tidak hanya mengerjakan latihan ketika latihan itu dikumpul atau akan mengikuti ujian, tetapi mereka mengerjakannya setiap saat waktu luang. Pada pelaksanaannya, mahasiswa diharapkan tidak hanya menyalin pekerjaan teman saja, tetapi dapat mempertanggung jawabkan hasil salinannya dan berpikir dalam mengerjakan lembar kerja. Mulai dari penyajian materi sampai ke soal latihan mahasiswa dilatih untuk mengembangkan dan meningkatkan sikap ilmiah.

\section{Hasil analisis Silabus mata kuliah Biologi Laut}

Dalam tahapan ini, dilakukan identifikasi hal-hal yang menjadi kebutuhan dalam pengembangan lembar kerja termasukidentitas mata kuliah Biologi Laut khususnya 
pada materi Produktivitas Perairan Ekosistem Laut. Dari hasil analisis diperoleh data bahwa mata kuliah Biologi Laut dengan kode BIO21164 merupakan mata kuliah wajib pada semester 6 dengan 2 SKS. Kemudian dilakukan analisis terhadap materi yang sesuai yang akan dikembangkan dalam lembar kerja agar tidak mengganggu ataupun menghambat perkuliahan mahasiswa semester 6 saat dilakukan penelitian. Dari hasil analisis tersebut diperoleh informasi bahwa mata kuliah Biologi Laut bahwa materi yang sesuai dengan perkuliahan smester 6 yang akan dikembangkan menjadi sebuah lebar kerja yaitu materi Produktivitas Perairan. Dengan Standar Kompotensi (SK) yaitu Produktivitas Perairan Ekosistem Laut, Kompetensi Dasar (KD) yaitu faktor abiotik dan faktor biotik, sedangkan indikatornya yaitu mengetahui tentang faktor abiotik dan faktor biotik yang berpengaruh dalm produktivitas perairan ekosistem laut.

\section{Hasil Review Buku Teks dan Lembar Kerja}

Setelah menganalisis silabus dan menentukan materi yang akan dikembangkan menjadi sebuah lembar kerja, selanjutnya dilakukan analisis terhadap buku teks yang berhubungan dengan Biologi Laut terutama materi Produktivitas Perairan untuk menetukan isi dari lembar kerja. Dari hail analisis diperoleh data bahwa buku yang digunakan dalam pengembangan lembar kerja ini mengacu pada buku teks yang digunakan oleh dosen dan mahasiswa serta materi yang ada pada buku Biologi Laut karangan Nyabakken, Ekologi Perairan karya Effendi dan beberapa literatur dari internet.

Lembar kerja berfungsi untuk membantu mahasiswa memahami materi perkuliahan dan kaya akan tugas. Lembar kerja berisi judul, petunjuk belajar, materi pokok, informasi pendukung, tugas dan penilaian. Lembar kerja ini disusun untuk meningkatkan sikap ilmiah mahasiswa pada mata kuliah Biologi Laut. Pemilihan soalsoal latihan dirancang dan disesuaikan untuk melatih dan meningkatkan sikap ilmiah mahasiswa yang akan berdampak terhadap hasil belajar mahasiswa. Dari hasil telaah literatur mengenai lembar kerja diperoleh informasi bahwa sebuah lembar kerja harus minimaL memiliki unsur-unsur seperti judul, petunjuk belajar, materi pokok, informasi pendukung, tugas dan penilaian. 


\section{Tahap Perancangan (design)}

Pengembangan Lembar Kerja mata kuliah Biologi Laut menggunakan aplikasi software Microsoft Office 2017, yaitu aplikasi Microsoft Word dan aplikasi Adobe Photoshop CS5. Lembar kerja didesain semenarik mungkin agar dapat menarik perhatian dan meningkatkan minat mahasiswa terhadap lembar kerja tersebut.Penelitian pengembangan lembar kerja mata kuliah Biologi Laut menggunakan ukuran kertas A4 dengan orientasi kertas potrait. Bagian kegiatan evaluasi lembar kerja yaitu kegiatan mengidentifikasi permasalahan dan memecahkan masalah berupa menjawab pertanyaan tentang faktor abiotik dan faktor biotik yang berpengaruh dalam produktivitas perairan ekosistem laut. Bagian kegiatan evaluasi berisi soal-soal yang membutuhkan pemikiran dan analisa mahasiswa secara mendalam. Soal-soal ini hanya bisa dijawab jika mahasiswa telah menguasai materi perkuliahan. Soal pada kegiatan ini adalah soal kemampuan berpikir tingkat tinggi yang dapat mendorong kreatifitas berpikir mahasiswa, sehingga terlatih untuk mengembangkan kemampuan berpikir tingkat tinggi yang akan meningkatkan sikap ilmiah mahasiswa. Berikut salah satu contoh kegiatan evaluasi pada lembar kerja.

\section{Tahap Pengembangan (develop)}

Setelah lembar kerja selesai dirancang, kemudian dilakukan tahap validasi. Kelayakan lembar kerja divalidasi oleh ahli media dan ahli materi. Penilaian meliputi check list rentang skor 1-4 menggunakan skala Gufman pada kesesuaian komponen kelayakan isi, kebahasaan dan penyajian.

Tabel 3.Hasil ValidasiMateri Lembar Kerja

\begin{tabular}{llll} 
No. & Komponen & Skor & Kriteria \\
$\mathbf{1}$ & Kelayakan Isi & $86,53 \%$ & Sangat Layak \\
$\mathbf{2}$ & Kebahasaan & $93,75 \%$ & Sangat Layak \\
$\mathbf{3}$ & Penyajian & $83,33 \%$ & Sangat Layak \\
Rata-rata & $87,87 \%$ & Sangat Layak \\
\hline
\end{tabular}

Hasil validasi materi lembar kerja pada mata kuliah Biologi Laut telah memenuhi kriteria lembar kerja yang sangat layak, karena pada komponen ketiga komponen kelayakan materi ketiganya memperoleh kriteia sangat layak yaitu 
komponen kelayakan isi $86,53 \%$, kebahasaan $93,75 \%$ dan penyajian $83,33 \%$. Berdasarkan hasil penilaian validator yang terlihat pada tabel 3 menunjukkan bahwa Lembar Kerja pada mata kuliah Biologi Laut telah mengacu kepada kategori Sangat Layak dengan nilai rata-rata 87,87\%. Angka yang diperoleh menunjukkan lembar kerja ini dapat digunakan setelah ada perubahan atau revisi yang dilakukan sesuai saran yang diberikan oleh validator.

Tabel 4. Hasil Validasi Media Lembar Kerja sebelum dan setelah Revisi

\begin{tabular}{lllll}
\hline Komponen & \multicolumn{2}{l}{ Sebelum revisi } & \multicolumn{2}{l}{ Setelah revisi } \\
\cline { 2 - 5 } & Skor & Kriteria & Skor & Kriteria \\
\hline Kelayakan Media & $62,50 \%$ & Cukup Layak & $82,14 \%$ & Sangat Layak \\
\hline
\end{tabular}

Hasil validasi media lembar kerja pada mata kuliah Biologi Laut yang meliputi ukuran lembar kerja, kepadatan halaman lembar kerja, Desain sampul, penomoran materi/subjudul/kegiatan, kejelasan materi, kejelasan instruksi, kesesuaian judul dengan materi, penggunaan petunjuk belajar, keterbacaan teks, kesesuaian pemilihan gambar, ketepatan penempatan gambar, pemilihan komposisi warna, pemilihan jenis dan ukuran font, kemudahan untuk dipahami masih mengacu pada kriteria cukup layak pada validasi I dengan persentase sebanyak 62,50\%. Pada validasi II atau setelah revisi berdasarkan masukan dari ahli media diperoleh hasil bahwa lembar kerja mata kuliah Biologi Laut telah mengacu pada kriteria lembar kerja yang sangat layak dengan skor persentase kelayakan $82,14 \%$.

\section{Hasil Revisi Produk}

Setelah dilakukan penilaian, revisi lembar kerja dilaksanakan berdasarkan saran dan masukan yang diberikan oleh ahli materi dan media.Masukan dan saran dari ahli materi dan media antara lain sebagai berikut: Identitas perguruan perlu dicantumkan, perlu kolom untuk identittas mahasiswa, Pemberian nomor sampel lembar kerja, Materi yang disajikan dalam lembar kerja kurang lengkap, penambahan gambar contoh/ilustrasi yang lebih banyak agar memudahkan pemahaman materi, pemilihan gambar contoh/ilustrasifaktor abitoik dan biotik yang lebih kontekstual padalembar kerja, penulisan unsur kimia masih perlu diperbaiki, referensi perlu dicantumkan, dan penyajian gambar-gambar yang dapat memacu rasa ingin tahu mahasiswa. Setelah dilakukan penilaian, revisi lembar kerja dilaksanakan berdasarkan saran dan masukan 
yang diberikan oleh ahli materi dan media. Masukan dan saran dari ahli materi dan media di antaranya identitas perguruan perlu dicantumkan, perlu kolom untuk identittas mahasiswa, pemberian nomor sampel lembar kerja, materi yang disajikan dalam lembar kerja kurang lengkap, penambahan gambar contoh/ilustrasi yang lebih banyak agar memudahkan pemahaman materi, pemilihan gambar contoh/ilustrasi faktor abitoik dan biotik yang lebih kontekstual pada lembar kerja, penulisan unsur kimia masih perlu diperbaiki, referensi perlu dicantumkan, penyajian gambar-gambar yang dapat memacu rasa ingin tahu mahasiswa. Setelah dilakukan revisi produk lembar kerja mata kuliah Biologi Laut, dilakukan tahap uji coba skala terbatas pada tanggal 22 Maret sampai 5 April 2018 pada 30 mahasiswa semester 6 jurusan Pendidikan Biologi STKIP Puangrimaggalatung Sengkang untuk mengetahui pengaruh lembar kerja ini terhadap peningkatan sikap ilmiah mahasiswa. Pada tahap uji coba ini terdapat 2 aspek yaitu sikap ilmiah dan hasil belajar.

\section{Tahap Penyebaran (disseminate)}

Tahap penyebaran atau uji coba terbatas produk lembar kerja mata kuliah Biologi Laut diterapkan pada 30 orang mahasiswa yang telah mengontrak Biologi Laut khususnya mahasiswa semester 6 yang dilakukan pada tanggal 22 Maret sampai 5 April 2018 di Kampus STKIP Puangrimaggalatung Sengkang. Pengambilan data keefektivan lembar kerja meliputi data tanggapan mahasiswa, data sikap ilmiah dan hasil belajar mahasiswa. Data tanggapan mahasiswa terhadap lembar kerja Biologi Laut diambil dengan teknik angket. Hasil analisis tanggapan mahasiswa yang terlihat pada tabel 5 menunjukkan bahwa mahasiswa menangggapi setuju dengan 90\% jawaban "ya" pada butir pertanyaan mengenai lembar kerja pada mata kuliah Biologi Laut. Data sikap ilmiah mahasiswa diambil dengan teknik observasi dalam pembelajaran. Data sikap ilmiah disajikan dalam tabel 5

Tabel 5. Data sikap ilmiah mahasiswa

\begin{tabular}{llll} 
No. & Kriteria & \multicolumn{2}{c}{ Jumlah Mahasiswa } \\
& & Pertemuan I & Pertemuan II \\
$\mathbf{1}$ & Sangat Baik & 0 & 17 \\
$\mathbf{2}$ & Baik & 4 & 11 \\
$\mathbf{3}$ & Cukup Baik & 22 & 0 \\
$\mathbf{4}$ & Tidak Baik & 0 & 0 \\
Total & & 26 & 28 \\
Rata-rata persentase & $56 \%$ & $83,04 \%$ \\
Rata-rata persentase klasikal & $69,52 \%$ &
\end{tabular}


Berdasarkan hasil penilaian oleh observer I dan observer II pada dua kali pertemuan yang terlihat pada Tabel 4.4. menunjukkan bahwa lembar kerja pada mata kuliah Biologi Laut dapat meningkatkan sikap ilmiah mahasiswa dengan persentase 69,52\% atau baik. Pengambilan data hasil belajar secara individu dilakukan sebanyak tiga kali yaitu tes awal (pretest) sebelum pembelajaran, tes akhir I (posttest I) setelah pembelajaran tanpa lembar kerja berakhir dan tes akhir II(posttest II) setelah pembelajaran dengan lembar kerja berakhir. Berdasarkan hasil uji coba yang terlihat pada Tabel 4.4 menunjukkan bahwa terjadi peningkatan hasil pretest, posttest I dan posttest II. Dengan rata-rata peningkatan yang baik yaitu $66,51 \%$ atau kriteria baik yang menunjukkn bahwa lembar kerja mata kuliah bilogi laut baik untuk hasil belajar mahasiswa.

Data sikap ilmiah mahasiswa diambil dengan teknik angket. Berdasarkan hasil analisis diperoleh hasil bahwa 90\% mahasiswa setuju dengan adanya pengembangan lembar kerja mata kuliah Biologi Laut dan 10\% yang tidak setuju. Berdasarkan data tersebut dapat disimpulkan bahwa tanggapan mahasiswa terhadap lembar kerja mata kuliah Biologi Laut sangat baik.

Data sikap ilmiah mahasiswa diambil dengan teknik observasi dalam pembelajaran. Berdasarkan hasil analisis diperoleh hasil bahwa terjadi peningkatan sikap ilmiah mahasiswa setelah penggunaan lembar kerja pada mata kuliah Biologi Laut. Hal ini terbukti dengan persentase sikap ilmiah mahasiswa pada pertemuan pertama atau sebelum penggunaan lembar kerja berada pada kriteria baik $=15,38 \%$, kriteria cukup baik $=84,62 \%$ dengan rata-rata persentase sikap ilmiah 56\%. Pada pertemuan kedua atau setelah penggunaan lembar kerja pada mata kuliah Biologi Laut, sikap ilmiah mahasiswa berada pada kriteria sangat baik $=60,71$ dan kriteria baik $=39,29 \%$ dengan rata-rata persentase sikap ilmiah 83,04\%. Hasil analisis tersebut menunjukkan peningkatan sikap ilmiah mahasiswa STKIP Puangrimaggalatung Sengkang setelah penggunaan lembar kerja. Hal ini sesuai dengan pendapat Fauzi (2015) bahwa lembar kerja untuk pembelajaran sains harus berdasarkan pada materi pelajaran, strategi dan juga harus mengembangkan keterampilan proses sains serta berpikir kritis terhadap pembelajaran sains.

Data hasil belajar mahasiswa diperoleh dari kegiatan evaluasi dengan pemberian tes uraian tertulis tentang materi produktivitas perairan. Dari hasil analisis data hasil belajar 
mahasiswa yang terdiri dari hasil pretest, posttes I dan posttes II dapat diketahui bahwa terjadi peningkatan hasil belajar mahasiswa setelah adanya penggunaan lembar kerja. Hal tersebut dapat dilihat pada hasil pretest dimana semua mahasiswa tidak lulus setelah mengerjakan soal pretest dengan nilai rata-rata uji coba 40,38\%, kemudian hasil posttes I menunjukkan peningkatan hasil belajar dengan persentase kelulusan mahasiswa mencapai kriteria baik dengan persentase kelulusan 73,08\% dengan nilai rata-rata uji coba $70,58 \%$, sedangakan hasil dari posttes II menunjukkan peningkatan hasil belajar mahasiswa yang signifikan dengan persentase kelulusan mencapai 100\% atau kriteria sangat baik dengan nilai rata-rata uji coba 88,57\%. Hal ini membuktikan bahwa sikap ilmiah dan hasil belajar akan berbanding lurus, sehingga dengan membaiknya sikap ilmiah mahasiswa maka hasil belajarnya juga akan membaik. Hal ini sesuai dengan Venny Haris (2014) bahwa lembar kerja mahasiswa berfungsi sebagai berikut : a). sebagai bahan ajar yang bisa meminimalkan peran pendidik, namun lebih mengaktifkan peserta didik, b) sebagai bahan ajar yang mempermudah peserta didik untuk memahami materi yang diberikan, c) sebagai bahan ajar yang ringkas dan kaya tugas untuk berlatih, dan d) memudahkan pelaksanaan pengajaran kepada peserta didik. Megawati (2008) menyatakan bahwa manfaat media pembelajaran dalam proses pembelajaran adalah pembelajaran akan lebih menarik perhatian siswa sehingga dapat menumbuhkan motivasi belajar, materi pembelajaran akan lebih jelas maknanya sehingga dapat lebih dipahami oleh para siswa dan memungkinkan siswa menguasai tujuan pembelajaran lebih baik

\section{SIMPULAN}

Berdasarkan hasil analisis data pada penelitian dan pembahasan dapat diketahui bahwa: 1). Lembar kerja (worksheet) mata kuliah biologi laut yang dikembangkan layak digunakan berdasarkan penilaian ahli materi sebesar $87,87 \%$ dengan kategori sangat layak, ahli media sebesar 82,14\% dengan kategori sangat layak dan tanggapan setuju mahasiswa sebanyak 90\%, dan 2). Pengembangan lembar kerja (worksheet) mata kuliah biologi laut dapat meningkatkan sikap ilmiah mahasiswa STKIP Puangrimaggalatung Sengkang. Dapat dilihat dari presentase sikap ilmiah mahasiswa pada pertemuan pertama atau sebelum penggunaan lembar kerja sebanyak 56\% dengan kategori cukup baik. Pada pertemuan kedua atau setelah penggunaan lembar kerja pada mata kuliah 
Biologi Laut terjadi peningkatan menjadi 83,04\% dengan kategori sangat baik. Dengan adanya pengembangan lembar kerja pada mata kuliah Biologi Laut dapat terjadi peningkatan sikap ilmiah mahasiswa pada proses pembelajaran mata kuliah Biologi Laut yang juga dapat meningkatkan hasil belajar mahasiswa pada mata kuliah Biologi Laut dengan persentase kelulusan setelah menggunakan lembar kerja mencapai $100 \%$ dengan rata-rata nilai hasil belajar sebanyak $66,51 \%$ atau kriteria baik.

\section{UCAPAN TERIMA KASIH}

Terima kasih kepada Ketua STKIP Puangrimaggalatung Sengkang atas kesempatan yang diberikan kepada dosen pengampuh mata kuliah untuk senantiasa berinovasi dalam mengembangkan bahan ajar dalam perkuliahan.

\section{DAFTAR PUSTAKA}

Haris, Venny. (2014). "Pengembangan Lembar Kerja (worksheets) pada Mata Kuliah Termodinamika untuk Melatih Kemampuan Berpikir Tingkat Tinggi Mahasiswa Fisika”. Tidak diterbitkan. Batusangkar: Prodi Tadris Fisika Jurusan Tarbiyah STAIN Batusangkar.

Haq, Nur Izzati, dkk. (2017). Tanpa tahun. "Pengembangan Worksheet Berbasis Keterampilan Proses Sains pada Materi Gelombang Mata Kuliah Fisika Dasar II". Pendidikan Fisika FKIP Universitas Jambi.

Hidayati, Alif Noor, (2014). "Sikap Ilmiah dan Budaya Berfikir Pada Kurikulum 2013" (https://pujiadilpmpjateng.wordpress.com/2014/05/17/sikap-ilmiah-dan-budayaberpikir-pada-kurikulum-2013/, diakses 19 Mei 2018).

Megawati S, Ruth Rize Paas. Dkk. (2015)."Perancangan Lembar Kerja Mahasiswa (LKM) Berbasis Mastery Learning Pada Mata Kuliah Genetika".Prosisiding Semirata 2015 bidang MIPA BKS-PTN Barat.Universita Tanjungpura Pontianak. Hal 57-64.

Rahmatika, Fitrianingsih. (2014). "Pengembangan Lembar Kerja Siswa Berbasis Search, Solve, Create, and Share pada Praktikum Mandiri Materi Mullusca dan Arthropoda”. Skripsi tidak diterbitkan.Semarang : Universitas Negeri Semarang.

Rokhimawan, Mohamad Agung. (2016). "Pengembangan LKM Berbasis Keterampilan Proses Sains pada Mata Kuliah Pembelajaran IPA MI 1". AL-BIDAYAH: Jurnal Pendidikan Dasar Islam Volume 8, Nomor 1, Juni 2016; ISSN : 2085-0034

Suryana, Ade. Dkk. (2013). Tanpa tahun.“Analisis Aktivitas dan Sikap Ilmiah Mahasiswa dengan Model Pengajaran Langsung Berbasis Inkuiri pada Mata Kuliah Siatematika Invertebrata".Fakultas Keguruan dan Ilmu Pendidikan Universitas Riau.

Suryani, Iis. (2013). "Pengembangan Instrumen Penilaian Sikap Ilmiah pada Pembelajaran dengan Model Latihan Penelitian di Sekolah Dasar". Pendidikan Guru Sekolah Dasar Universitas Pendidikan Indonesia Kampus Tasik Malaya. 
Trisianawati, Eka dan Darmawan, Handy. (2017). "Pengembangn Lembar Kegiatan Mahasiswa Berbasis Model Guided Inquiry untuk Meningkatkan Keterampilan Proses Sains Mahasiswa". Jurnal Ilmiah Ilmu Pendidikan Vol. 8 No. 2 Nopember 2017; ISSN: 2086-4450.

Yani, Ahmad. Haerunnisa, Sahriah. (2017).“Analisis Aktivitas dan Sikap Ilmiah Mahasiswa melalui Model Pembelajaran Project Based Learning (PjBL) pada Perkuliahan Biologi Air Tawar STKIP Puangrimaggalatung Sengkang Sul-Sel”. Prosiding Seminar Nasional III, tahun 2017. 